\title{
Greenhouse gas emissions related to biodiesel from traditional soybean farming compared to integrated crop-livestock systems
}

\author{
Elisa Maria Mano Esteves ${ }^{a}$ * , Victor Paulo Peçanha Esteves ${ }^{b}$, Davi José Bungenstab ${ }^{\text {, }}$ \\ Ofélia de Queiroz Fernandes Araújo ${ }^{\text {b }}$, Cláudia do Rosário Vaz Morgado ${ }^{\text {a }}$ \\ ${ }^{a}$ Environmental Engineering Program (PEA), Federal University of Rio de Janeiro, Rio de Janeiro, RJ, Brazil \\ b Program in Chemical and Biochemical Process Technology (TPQB), Federal University of Rio de Janeiro, Rio de Janeiro, RJ, Brazil \\ ${ }^{\mathrm{c}}$ National Center for Beef Cattle Research (CNPGC), Brazilian Agricultural Research Corporation (Embrapa), Campo Grande, MS, Brazil
}

\section{A R T I C L E I N F O}

\section{Article history:}

Received 5 January 2017

Received in revised form

16 November 2017

Accepted 29 December 2017

Available online 11 January 2018

\section{Keywords:}

Biodiesel

Soybean

Greenhouse gases (GHG) emissions

Life cycle assessment (LCA)

Integrated crop-livestock system (ICLS)

\begin{abstract}
A B S T R A C T
Biodiesel has great potential to reduce greenhouse gas emissions, as an alternative to fossil diesel. However, its production occurs under different agricultural systems, with different levels of emissions in the farming phase. Integrated crop-livestock systems can play an important role in this sense, since they combine livestock with crop farming, optimizing land and input usage, with good potential to reduce total emissions from energy and food agriculture. This study compares integrated crop-livestock systems with traditional soybean farming systems regarding biodiesel production, through life-cycle assessment. Additionally, it compares different integrated crop-livestock systems in Central Brazil, to evaluate their impact regarding greenhouse gas emissions. The life cycle assessment performed adopts two approaches to apportion the farming phase emissions (sub-process division and system expansion), as well as two functional units (emissions per hectare and per kilogram of biodiesel). The system expansion approach appears to be the most suitable because the studied agropastoral systems have strong reciprocal relationship and exchange of benefits among the different farming activities. This approach also considers co-products as avoided products, showing that the whole integrated system is environmentally more attractive due to negative emissions. When analyzing only biodiesel production, results show no substantial difference between traditional and integrated systems. Therefore, the factors with the greatest impact on biodiesel production, concerning GHG emissions, are the frequency of rotation (pasture/crop) and type of management in the agricultural system.
\end{abstract}

๑) 2018 Elsevier Ltd. All rights reserved.

\section{Introduction}

Use of fossil fuels raises concerns due to economic dependence and uncertainties over future availability, since they are not renewable (Rajaeifar et al., 2014). According to Lin et al. (2014), biomass is the renewable energy source with the greatest potential to supply energy needs. However, since biomass can also be a source of food, detailed studies are necessary to assure that land use for energy production does not interfere with necessary food production, particularly in emerging markets (UNFCCC, 1994).

Biofuels, especially ethanol and biodiesel, are effective ways to obtain energy from biomass. These fuels are utilized because: a) they are renewable and biodegradable; $b$ ) they usually have a better

\footnotetext{
* Corresponding author.

E-mail address: elisa.esteves@poli.ufrj.br (E.M.M. Esteves).
}

carbon emissions balance to the atmosphere (carbon released from combustion was previously absorbed by plant during growth) and c) their production can promote rural development (Peters and Thielmann, 2008).

Regarding biodiesel, Brazil is one of the world's leading soybean producers, and this crop is the main raw material for biodiesel in the country. Development of varieties that can thrive in the country's diverse environments through application of appropriate soil management practices has allowed soybean cultivation to expand dramatically, particularly in the Midwest region. This expansion has been largely driven by international demand, mainly from China (Raucci et al., 2015). Brazilian grain production growth is reflected in exports, since the quantity processed stays stable (Fig. 1). Most of the soybean not exported is used to make meal (for animal feed and to compose human foods) along with cooking oil.

In 2014 , only $43 \%$ of the soybean crop was domestically processed into oil and meal. Of the extracted oil, 20\% was exported, 55\% 


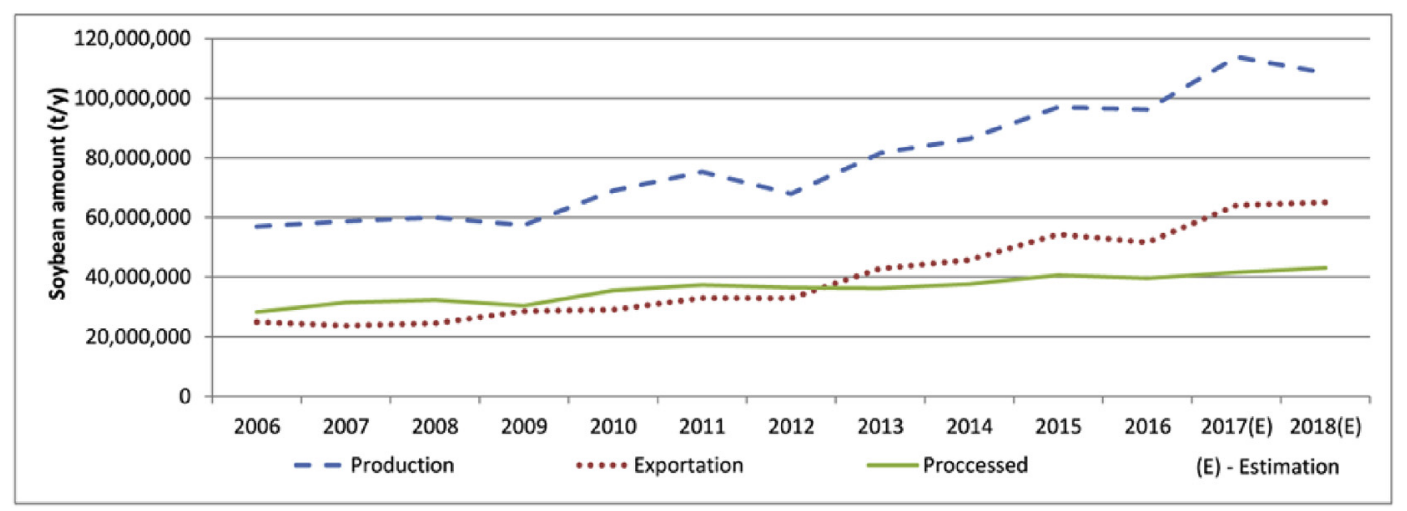

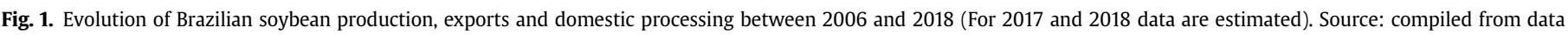
from ABIOVE (2017).

was refined for cooking oil or animal feed additive and 25\% was used to produce biodiesel (CONAB, 2015). In 2005, the abundance of soybean oil in the market and consequent reduction in prices was a main factor for establishing the National Program for Biodiesel Production and Use (PNPB) (Brondani et al., 2015). Since 2006, when commercial production of biodiesel began, crude soybean oil has been the major raw material for biodiesel production. In 2015, it accounted for $77.4 \%$ of the raw material used for biodiesel (MME, 2016).

Nevertheless, crop cultivation for energy production has attracted criticism related to consumption of agricultural inputs, carbon and water footprint, competition with food crops and pressure on natural biomes (Hausman, 2012). This is particularly true for Brazil's Midwest region, where rapid expansion of farming and livestock grazing into the Cerrado and Amazon biomes has led to an important debate. A particular issue is the fact that the region's soils are generally acidic, with low fertility, revealing degradation in different degrees, especially in poorly managed sown pastures (Figueiredo et al., 2017).

Starting in the 1800s, the main agricultural activity in Brazil's Midwest region was extensive cattle grazing on the original Savannah lands. In the 1970s, the process of replacing native by sown pastures started, supported by soil fertility improvements, especially by applying lime to increase $\mathrm{pH}$. This led to strong herd growth and consequently growth in beef production, with a positive impact on the economy.

Cattle grazing in Brazil happens mostly in marginal areas for crops, in rather extensive systems, with relatively low profit margins. For this reason, ranchers tend not to fertilize pastures. Besides this, trying to compensate for low profit margins, farmers also tend to keep herd numbers above recommendable stocking rates, causing overgrazing, which, most of the time lead to pasture degradation (Gil et al., 2015; Figueiredo et al., 2017). Over time, parts of such grazing areas were converted to crop farming, especially soybeans, with advanced soil management practices, including no-till systems, which greatly improve fertility and resolve erosion issues. For instance, in the state of Mato Grosso do Sul alone, between 1993 and 2013, 92\% of new crop farming areas simply replaced pastures (Esteves et al., 2016), thus not involving forest clearance. Increasing grain production for biodiesel in the area does not imply deforestation and its associated environmental impacts.

With increasing soybean farming, cattle grazing areas are reduced. The loss of pasture areas was not accompanied by a reduction in the size of the cattle herd, indicating higher stocking rates due to a tendency to use the confinement system (Esteves et al., 2017). Thus, to maintain earnings, it is necessary to develop sustainable systems with integrated production to optimize land use, by obtaining different products in the same area (Silva et al., 2015). In this scenario, the use of integrated crop-livestock systems (ICLS) is a good land-management option, not only to restore degraded pastures (Figueiredo et al., 2017), but also to maintain beef production while allowing grain production under better agricultural practices, and vice versa. These systems involve simultaneous, sequential or rotational, cultivation in the same area, with no-tillage management to optimize use of inputs and farm machinery. Such systems optimize biological cycles, consequently increasing yields (Franzluebbers and Stuedemann 2014; Salton et al., 2014). These systems also can increase small farmers' income and improve social conditions in rural areas and diminish environmental impacts, enhancing sustainability (Pariz et al., 2017). The establishment of ICLS is a promising alternative to improve sustainability of agriculture (Paolotti et al., 2016), especially regarding climate change and price volatility of commodities and inputs (Lemaire et al., 2014).

In Brazil, ICLS usually combines traditional soybean farming, sown in October, as a summer crop, followed by maize as an interseasonal crop, with emerging use of cattle grazing over maize crop residues (Gil et al., 2015) or under other variable husbandry systems (Balbino et al., 2014). This land use strategy brings substantial advantages compared to traditional soybean cultivation, since environmental impacts related to energy use and greenhouse gas (GHG) emissions are shared by all outputs from the system. Additionally, the ability to cultivate crops to produce biofuels in marginal lands can help the recovery of degraded areas, making them productive again and reducing pressure to clear native vegetation for new cropland (German et al., 2011). Outputs from these production systems are also major commodities and therefore essential for Brazilian economy, since the country is a global player also in maize (USDA, 2017) and beef markets (FAS/USDA 2016).

Cobucci et al. (2007) and Kichel et al. (2011) confirm the economic potential of ICLS in substitution of degraded pasture, improving cattle yields and consequently boosting beef production (Table 1). Nevertheless, despite high yields and attractive net income of ICLS, adoption rates of these systems are still low, since implementation and maintenance costs are much higher than traditional livestock systems.

Although Brazil has a substantial number of published studies on ICLS (Moraes et al., 2014), precise statistics on areas under ICLS are not available. According to Balbino et al. (2012), the total area using ICLS will almost triple by 2020 , considering an estimated area of 1.6 million hectares in 2012.

Figueiredo et al. (2017) evaluated GHG emissions and carbon footprint of beef cattle in different pasture-management systems. 
Table 1

Comparison of productivity, costs, gross and net income between rearing finishing cattle through ICLS and degraded pasture grazing.

\begin{tabular}{|c|c|c|c|c|c|}
\hline \multirow[t]{2}{*}{ Management } & \multirow[t]{2}{*}{ Products } & \multirow{2}{*}{$\frac{\text { Yield }}{\text { (kg/ha per year) }}$} & Cost & Gross income & Net income \\
\hline & & & \multicolumn{3}{|c|}{ (US\$/ha per year) } \\
\hline \multirow[t]{4}{*}{ Integrated crop-livestock system (ICLS) } & Soybean & 3480.00 & 698.40 & 1181.40 & 483.10 \\
\hline & Maize & 2262.00 & 331.80 & 344.60 & 12.90 \\
\hline & Beef & 471.00 & 792.60 & 1644.70 & 852.20 \\
\hline & Total & - & 1822.80 & 3170.70 & 1348.20 \\
\hline Livestock on degraded pasture & Beef & 60.00 & 163.00 & 209.60 & 46.60 \\
\hline
\end{tabular}

Source: Adapted from Kichel et al. (2011).

Schuster et al. (2016) investigated effects of different grazing intensities on weed seedling emergence in ICLS. Gil et al. (2015) studied the current status of integrated systems and the potential for dissemination among farmers in Mato Grosso do Sul, Brazil. Salton et al. (2014) compared conventional tillage, no tillage, integrated crop-livestock and pasture under no-tillage to evaluate the performance. Franzluebbers and Stuedemann (2014) analyzed yield responses to tillage and cover crop management in ICLS. Lemaire et al. (2014) studied strategies to obtain better environmental quality in agriculture production considering ICLS. However, none of these investigations compared different types of integrated systems. Besides this, none of them addressed integrated systems aimed at biofuel production from agricultural raw materials.

In this context, determining net environmental effects of a product that can be obtained through different production systems requires knowledge of impacts during all its production stages, from "cradle to grave". Life-cycle assessment (LCA) is suitable for this approach. But applying LCA to ICLS poses challenges, since integration can involve a wide range of alternatives and different practices between cropping and grazing activities (Silva et al., 2015), which makes the analysis complex. Therefore, the goal of this study is to verify whether ICLS are environmentally beneficial, regarding soybean biodiesel GHG emissions, compared to traditional soybean farming systems. This is accomplished through a LCA of soybean biodiesel from both systems and finally comparing different ICLS to quantify differences among them.

\section{Method}

The objective and scope of the LCA developed in this work is to estimate GHG emissions of soybean biodiesel, from different farming operations until obtaining commercial biodiesel from the transesterification plant. The intention is to compare farming production systems, therefore no baseline data are used. For each phase of the LCA, entry of products from the previous phase is considered, as well as inputs. The focus is atmospheric GHG emissions, so emissions to soil and water are not considered here.

Fig. 2 presents the phases of the biodiesel production process considered. The agricultural phase is assessed through data from five case study farms in the municipality of Maracajú, in the Dourados micro-region (DMR) of the state of Mato Grosso do Sul (MS). This micro-region produces nearly $50 \%$ of the total volume of soybeans in the state, and Maracajú accounts for about $22 \%$ of the output from the DMR.

Biodiesel is the system's target product, so the main products from the production flow are soybean grain and soybean oil. Maize, beef (measured by cattle live weight gain - LWG - for integrated systems) and soybean meal are co-products, and glycerin is a byproduct of the process. Detailed emissions due to products, byproducts and co-products are listed in section 2.1, where the approaches to apportion emissions are presented.

Five soybean farms, representative of the study region, were selected. Two of them produce only soybeans and maize

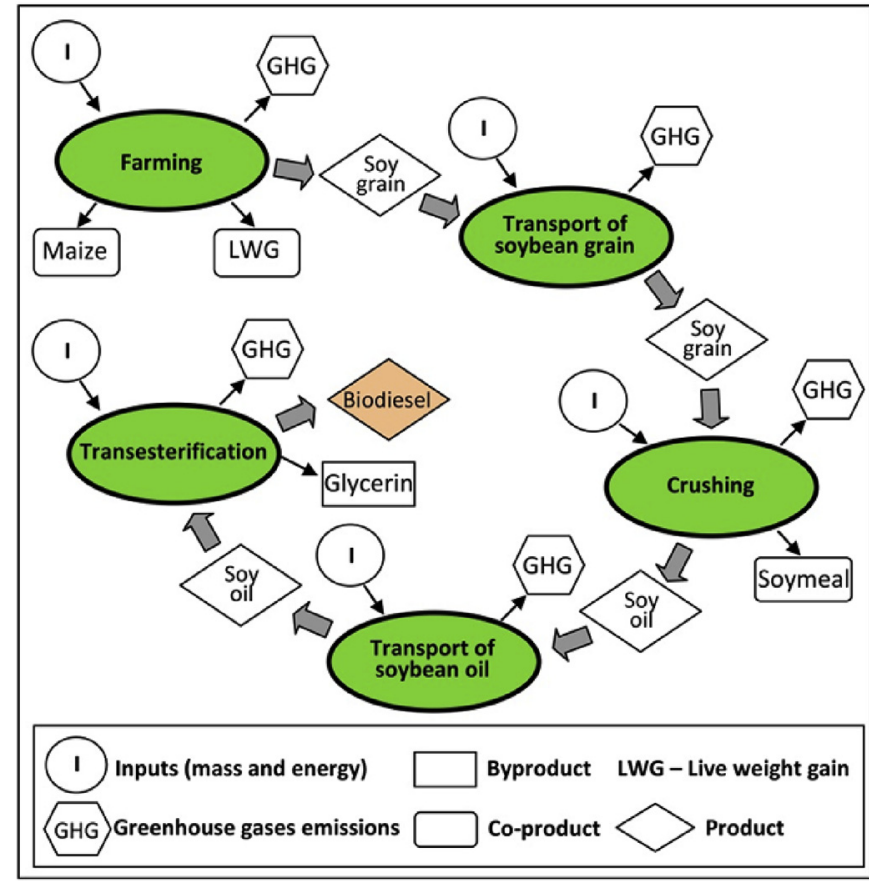

Fig. 2. Biodiesel production flow.

(traditional farms) and the other three use different modalities of crop-livestock integration, though all have soybeans as the major output.

Calculations regarding emissions from stock breeding are based on inputs necessary for cattle husbandry, like grazing grass and other roughage cultivation, also including emissions from animals kept in the ICLS areas; amount of supplementary dry feed used and the total weight gain of these animals during the fattening period. This work considered only the fattening period, because in the studied area most integrated farms acquire adult cattle for fattening.

The period considered is one year, starting in October 2013, when the soybean crop was sown. GHG emissions are assessed by two different functional units: (a) 1 ha (ha) of soybean crop to produce biodiesel and (b) $1 \mathrm{~kg}$ of biodiesel produced. GHG emissions are calculated using SimaPro ${ }^{\circledR}$ (version 8), specifically the Ecoinvent 3 database, considering the current technological package for soybean production in the region studied. Inputs for manufacturing related machines and infrastructure were considered insignificant and therefore are left out the calculations.

Regarding GHG emissions per hectare, the total emissions due to the agricultural production phase (soybean, maize and cattle) have to be divided by the total area of the farm because this work aims to evaluate global impact per hectare of the farm and not the impact of processes individually. 
To assess the amounts of GHG released and the consequent effect on global warming through their buildup in the atmosphere, the impact evaluation method of the Intergovernmental Panel on Climate Change (IPCC) is used, applying global warming potential (GWP) of each of the main gases in the atmosphere. The evaluation is performed for the worst-case scenario with a horizon of 20 years: "IPCC, 2007 GWP 20".

\subsection{Apportioning emissions approaches}

LCA is a technique that allows identifying the overall environmental effects of the life cycle of a product or process, by evaluating the potential environmental impacts of a system through detailed study of the inputs of energy and mass in the production life cycle, including transportation. ISO 14044:2006 (ISO, 2006) approach has been widely used in LCA, allowing a standard base of comparison.

According to ISO (2006), for multiple output processes, it is necessary to apportion emissions among the given products. This is also true when the system's outputs have high market value, as in the case of this study, where maize, beef and soybean meal are all important commodities. Local soybean production and soybean industrial processing generate other valuable products. The outputs that have similar value to that of the main product are named coproducts, while the products that have lower value than the main product are named byproducts (Horne and Matthews, 2004).

Therefore, it is necessary to adopt an approach to apportion emissions among products (soybean grain and soybean oil), coproducts (maize, LWG and soybean meal) and byproduct (glycerin) throughout the biodiesel production chain. Soybeans and consequently biodiesel, are not the only high-value products of the system, so they cannot be held responsible for all emissions from the farming and industrial phases.

The simplest way to apportion impacts among the different outputs is the allocation method, which splits the system's inputs and impacts among outputs using their physical or economic interrelationships. Three basic allocation methods are used: based on mass, on energy content or on market value. Mass allocation takes into consideration the mass fraction of products and co-products obtained in the phases, while market value and energy allocations, besides the mass ratio, use the commercial value and the lower heating value (LHV) of each product and co-product. However, ISO 14,044:2006 (ISO, 2006) recommends avoiding allocation using two approaches: a) sub-processes division (SD), where elementary processes can be reorganized into sub-processes, having one for each system's product, with entry data also collected for each of them; and b) system expansion (SE) which includes in the inventory all inputs and outputs related to the co-products, deducting from the final total impacts of the studied system the respective amount of emissions of these co-products if they were obtained somewhere else, in another production system.

\subsubsection{Apportioning farming phase emissions}

As shown in Fig. 2, two co-products are produced by the farming phase besides the major product, soybean grain: maize and LWG. The three products from the farming phase have a common input shared by the three activities (soybean cultivation, maize cultivation and cattle grazing), the soil. All other mass and energy entries can be split to create three independent sub-processes. In this case, the sub-processes division (SD) approach involves creating one independent sub-process for each of the three final products. Independence in this case is numerical, since inputs, soil and pest management practices from one activity influence the other. In the region studied, integrated systems tend to have better results. However, these reciprocal influences are hard to measure. They demand specific investigations, so their assessment is not in the scope of this work, where the intention is only to measure the impact of biodiesel produced by these different systems. Because it does not consider the interaction of activities, the SD approach is not the most suitable. However, to allow comparisons with the SE approach and other studies that have employed the SD approach, calculations with SD are also presented.

Under the SE approach, it is assumed that the co-products maize and LWG are incorporated into the system and all inputs are related to a single process, considering that the whole farm management integrates the three farming activities. In this approach, maize and LWG are counted as avoided products. Thus, emissions to produce an equal quantity of these products elsewhere, under other management systems, are considered as negative impacts (credits). The main weakness factor of this approach is the many possible figures for emission rates of these products due to the variety of possible locations and management systems to obtain these avoided products. Nevertheless, the SE approach is more suitable because it considers the benefits of the interaction of activities.

\subsubsection{Industrial phase's allocation}

This study considers only the two main products obtained from each industrial phase: soybean oil and meal from extraction, and biodiesel and glycerin from transesterification. For the extraction process, neither the SD nor the SE approaches can be adopted. Soybean meal production cannot be dissociated from oil production, since the only way to obtain soybean meal is to extract soybean oil from the grain.

For the transesterification process, it is not possible to physically separate mass and energy entries responsible for biodiesel and glycerin production, preventing use of the SD approach. Analogously, apportioning using SE is not appropriate once the world's glycerin production is also based on the transesterification process for biodiesel production (Tan et al., 2013).

For each kilogram of soybean grain entering the extraction process, $180 \mathrm{~g}$ of oil and $813 \mathrm{~g}$ of meal are obtained (Cavalett and Ortega, 2010). The average market prices for the one-year study period (January 2014 to December 2014) of crude soybean oil and soybean meal, obtained from companies operating in the region, were respectively US\$0.82 and US\$0.45 per kilogram (CRCPBAF, 2016). To calculate the energy allocation factor, the LHV of the oil and meal was used, with values of $34.04 \mathrm{MJ} / \mathrm{kg}$ (Mourad and Walter, 2011) and $15.40 \mathrm{MJ} / \mathrm{kg}$ (Patzek, 2009).

According to the data from local companies, for each kilogram of soybean oil processed, $103 \mathrm{~g}$ of crude glycerin (with $80 \%$ glycerol) and $879 \mathrm{~g}$ of biodiesel are obtained. Average market prices for the study period of biodiesel and crude glycerin were, respectively, US\$0.73/kg (MME, 2015) and US\$0.10/kg (CRCPBAF, 2016). For energy allocation, LHV of $14.3 \mathrm{MJ} / \mathrm{kg}$ (Albarelli et al., 2011) for glycerin and $39.0 \mathrm{MJ} / \mathrm{kg}$ (Rocha et al., 2014) for biodiesel were used.

Table 2 presents mass quantities per kilogram of processed soybean grain and oil, the corresponding market values and LHV, along with mass, market value and energy allocation factors.

A deeper analysis shows there is no allocation method fully appropriate for this study. With respect to the allocation in the oil extraction process, the oil itself has a mass value one-fourth that of soybean meal, which is a co-product. Therefore, using mass as allocation parameter underestimates the impact of the final target product, biodiesel. When using energy content, the difference is smaller, since oil has energy value per kilogram two times higher than meal. Allocation using market value leads to a similar figure, once the proportions are also around 2:1. However, this method has uncertainty associated with market fluctuations.

In the transesterification process, the difference among allocation factors is less than 9\%. Biodiesel has LHV almost three times larger than glycerin and this makes the energy allocation factor $7 \%$ 
Table 2

Allocation factors for industrial processes.

\begin{tabular}{|c|c|c|c|c|c|c|c|}
\hline & & $\begin{array}{l}\text { Mass }(\mathrm{kg} / \mathrm{kg} \\
\text { of product) }\end{array}$ & $\begin{array}{l}\text { Market value } \\
\text { (US\$/kg) }\end{array}$ & LHV (MJ/kg) & Mass allocation & $\begin{array}{l}\text { Market value } \\
\text { allocation }\end{array}$ & Energy allocation \\
\hline \multirow[t]{2}{*}{ Oil extraction } & Oil & 0.18 & 0.82 & 34.04 & $\mathrm{AF}_{\mathrm{e}}[\mathrm{m}]^{\mathrm{a}}=18.2 \%$ & $\mathrm{AF}_{\mathrm{e}}[\mathrm{v}]^{\mathrm{a}}=29.0 \%$ & $\mathrm{AFe}[\mathrm{e}]^{\mathrm{a}}=32.9 \%$ \\
\hline & Meal & 0.81 & 0.45 & 15.40 & $81.8 \%$ & $71.0 \%$ & $67.1 \%$ \\
\hline \multirow[t]{2}{*}{ Transesterification } & Biodiesel & 0.879 & 0.73 & 39.00 & $\mathrm{AF}_{\mathrm{t}}[\mathrm{m}]^{\mathrm{b}}=89.5 \%$ & $\mathrm{AF}_{\mathrm{t}}[\mathrm{v}]^{\mathrm{b}}=98.4 \%$ & AFt $[\mathrm{e}]^{\mathrm{b}}=95.9 \%$ \\
\hline & Glycerin & 0.103 & 0.10 & 14.30 & $10.5 \%$ & $1.6 \%$ & $4.1 \%$ \\
\hline
\end{tabular}

a $\mathrm{AF}_{\mathrm{e}}[\mathrm{x}]$ indicates the allocation methods for the extraction process.

b $\mathrm{AF}_{\mathrm{t}}[\mathrm{x}]$ indicates the allocation methods for the transesterification process, " $\mathrm{x}$ " is " $\mathrm{m}$ " for mass allocation, " $\mathrm{v}$ " for market value allocation or "e" for energy allocation.

larger than the mass allocation factor. The market value allocation factor is even higher (almost 10\%) because biodiesel prices are over seven times higher than glycerin prices.

Table 3 shows the nine options for accumulated allocation factors $\left(\mathrm{AF}_{\mathrm{a}}\right)$, i.e., the product of the oil extraction phase (consisting of the products of the oil extraction and its serial upstream phases, $\left.\mathrm{AF}_{\mathrm{e}}\right)$ and the transesterification phase $\left(\mathrm{AF}_{\mathrm{t}}\right)$; each expressed as mass $([\mathrm{m}])$, market value $([\mathrm{v}])$ and energy $([\mathrm{e}])$. For instance, the accumulated allocation factor using mass allocation for the oil extraction and market value for transesterification is expressed in Table 3 as $\mathrm{AF}_{\mathrm{a}}[\mathrm{m}, \mathrm{v}]$. This work adopts the average factors of the transesterification phase $\left(\mathrm{AF}_{\mathrm{t}, \text { mean }}\right)$ to produce the mean accumulated factor $\left(\mathrm{AF}_{\mathrm{a}, \mathrm{mean}}\right)$, because none of the three individual allocation approaches is unanimously accepted.

The impact metrics from the agricultural, soybean transport and oil extraction phases are multiplied by the accumulated allocation factor. The study considers the mean of accumulated allocation factors under the same allocation method $\left(\mathrm{AF}_{\mathrm{a}}[\mathrm{m}, \mathrm{m}], \mathrm{AF}_{\mathrm{a}}[\mathrm{e}, \mathrm{e}]\right.$ and $\left.\mathrm{AF}_{\mathrm{a}}[\mathrm{v}, \mathrm{v}]\right): \mathrm{AF}_{\mathrm{a} \text { mean }}=25.5 \%$.

For the oil transport and transesterification phases, impacts are multiplied by the mean of transesterification allocation factors $\left(\mathrm{AF}_{\mathrm{t}}\right.$ [m], $\mathrm{AF}_{\mathrm{t}}[\mathrm{e}]$ and $\left.\mathrm{AF}_{\mathrm{t}}[\mathrm{v}]\right): \mathrm{AF}_{\mathrm{t} \text { mean }}=94.6 \%$.

\subsection{Inventory analysis}

\subsubsection{Farming phase}

As usual for the region, all five farms studied grow a soybean crop in summer followed by a maize crop in the inter-season, the latter seeded with palisade grass (Brachiaria sp.) between rows. Soybean is sown as the summer crop (October to March), followed by sowing of maize interspersed with palisade grass (Februar$\mathrm{y}$-March). Three of the farms also produce beef through ICLS, but they also use the same technology package for soybean and maize production as the two traditional farms. The ICLS farms' strategy is to combine cropping with cattle breeding, though varying grazing and feeding periods, animal ages and types of feeding among them.

The Brazilian Cerrado (Savanna) has large agricultural production, but compared to other agricultural areas in the world, even after several years of cultivation, it is still dependent on fertilizers (nitrogen, phosphorous and potash), as well as soil correction inputs like lime and gypsum to increase soil pH. As usual, herbicides, insecticides and fungicides are necessary to control weeds and pests during the production cycle. Due to their importance, these inputs are counted in the analysis, as well as energy inputs (fuels that power the machines used in the respective field operations).

Average rainfall in the region is around $1800 \mathrm{~mm} / \mathrm{year}, 80 \%$ of it concentrated between October and April (INMET, 2014). This makes irrigation financially unattractive for growing soybeans in the area, as is the case in most areas of Brazil. In the inter-season, the local dry season, photoperiods are too short to make good use of extra water from irrigation, rendering it unattractive also for the maize crop. Despite this, soybeans are sufficiently resistant to short droughts so that production is not totally compromised by dry spells (Marzullo, 2007).

Soybeans generally do not require drying, because moisture content at harvest is typically near the recommended level for processing (14\%). In contrast, maize invariably needs drying, since the kernels have higher moisture content than suitable for storage. Three of the studied farms dry their crops in conventional grain dryers heated by firewood, while two use natural gas.

Farm 4 and Farm 5 use traditional soybean-maize crop rotation, having no cattle husbandry and using $100 \%$ of their area to grow soybeans in the summer (October to March) followed by maize (March to September). Maize is inter-seeded with palisade grass to provide ground cover, essential for no-till farming, thus boosting soybean yields (Fig. 3 ).

On Farm 1, cattle are fattened in feedlots, with dry feed available $24 \mathrm{~h}$ a day, during 10-11 months a year. Prior to this, the cattle graze on palisade grass for 30-60 days in one of five areas where maize has just been harvested. Also, the area utilized for winter pasture is switched every five years (Fig. 4).

Farm 2 is divided in 6 paddocks of 400 ha each, one of them (R1 in Fig. 5) set aside from the total area of 2400 ha. This paddock is used for cattle finishing. In the cropped area, palisade grass is associated with maize only for soil cover, not being used for grazing. In this farm, cattle receive dry feed (about $1 \%$ of live weight on dry matter basis) twice a day in pasture. The ICLS of this farm is basically characterized by rotating the paddock area with crops every five years.

Table 3

Accumulated allocation factors.

\begin{tabular}{|c|c|c|c|c|c|}
\hline & & \multicolumn{4}{|l|}{ Transesterification } \\
\hline & & $\mathrm{AF}_{\mathrm{t}}[\mathrm{m}]^{\mathrm{c}}=89.5 \%$ & $\mathrm{AF}_{\mathrm{t}}[\mathrm{v}]^{\mathrm{c}}=98.4 \%$ & $\mathrm{AF}_{\mathrm{t}}[\mathrm{e}]^{\mathrm{c}}=95.9 \%$ & $\mathrm{AF}_{\mathrm{t} \text { mean }}{ }^{\mathrm{d}}=94.6 \%$ \\
\hline Oil Extraction & $\begin{array}{l}\mathrm{AF}_{\mathrm{e}}[\mathrm{m}]^{\mathrm{a}}=18.2 \% \\
\mathrm{AF}_{\mathrm{e}}[\mathrm{v}]^{\mathrm{a}}=29.0 \% \\
\mathrm{AF}_{\mathrm{e}}[\mathrm{e}]^{\mathrm{a}}=32.9 \%\end{array}$ & $\begin{array}{l}\mathrm{AF}_{\mathrm{a}}[\mathrm{m}, \mathrm{m}]^{\mathrm{e}}=16.3 \% \\
\mathrm{AF}_{\mathrm{a}}[\mathrm{v}, \mathrm{m}]^{\mathrm{e}}=26.0 \% \\
\mathrm{AF}_{\mathrm{a}}[\mathrm{e}, \mathrm{m}]^{\mathrm{e}}=29.5 \%\end{array}$ & $\begin{array}{l}\mathrm{AF}_{\mathrm{a}}[\mathrm{m}, \mathrm{v}]^{\mathrm{e}}=17.9 \% \\
\mathrm{AF}_{\mathrm{a}}[\mathrm{v}, \mathrm{v}]^{\mathrm{e}}=28.6 \% \\
\mathrm{AF}_{\mathrm{a}}[\mathrm{e}, \mathrm{v}]^{\mathrm{e}}=32.4 \%\end{array}$ & $\begin{array}{l}\mathrm{AF}_{\mathrm{a}}[\mathrm{m}, \mathrm{e}]^{\mathrm{e}}=17.4 \% \\
\mathrm{AF}_{\mathrm{a}}[\mathrm{v}, \mathrm{e}]^{\mathrm{e}}=27.8 \% \\
\mathrm{AF}_{\mathrm{a}}[\mathrm{e}, \mathrm{e}]^{\mathrm{e}}=31.6 \%\end{array}$ & $\mathrm{AF}_{\mathrm{a} \text { mean }}{ }^{\mathrm{b}}=25.5 \%$ \\
\hline \multicolumn{6}{|c|}{$\begin{array}{l}\text { a } \mathrm{AF}_{\mathrm{e}}[\mathrm{x}] \text { is the allocation factor for extraction process using allocation approach " } \mathrm{x} \text { ", where " } \mathrm{x} \text { " can be "m" (mass-based), " } \mathrm{v} \text { " (market value) or "e" (energy) } \\
\mathrm{b} \mathrm{AF}_{\mathrm{a} \text { mean }} \text { is mean accumulated allocation factor. } \\
\text { c } \mathrm{AF}_{\mathrm{t}}[\mathrm{y}] \text { is the allocation factor for transesterification using allocation approach " } \mathrm{y} \text { ", where " } \mathrm{y} \text { " can be "m" (mass-based), " } \mathrm{v} \text { " (market value) or "e" (energy) } \\
\mathrm{d} \mathrm{AF}_{\mathrm{t} \text { mean }} \text { is the mean allocation factor for transesterification. } \\
\text { e } \mathrm{AF}_{\mathrm{a}}[\mathrm{x}, \mathrm{y}] \text { is the accumulated allocation factor of approach " } \mathrm{x} \text { " for extraction and approach " } \mathrm{y} \text { " for transesterification, where " } \mathrm{x} \text { " and " } \mathrm{y} \text { " can be "m" } \\
\text { mass-based), " } \mathrm{v} \text { " (market value) or "e" (energy). }\end{array}$} \\
\hline
\end{tabular}




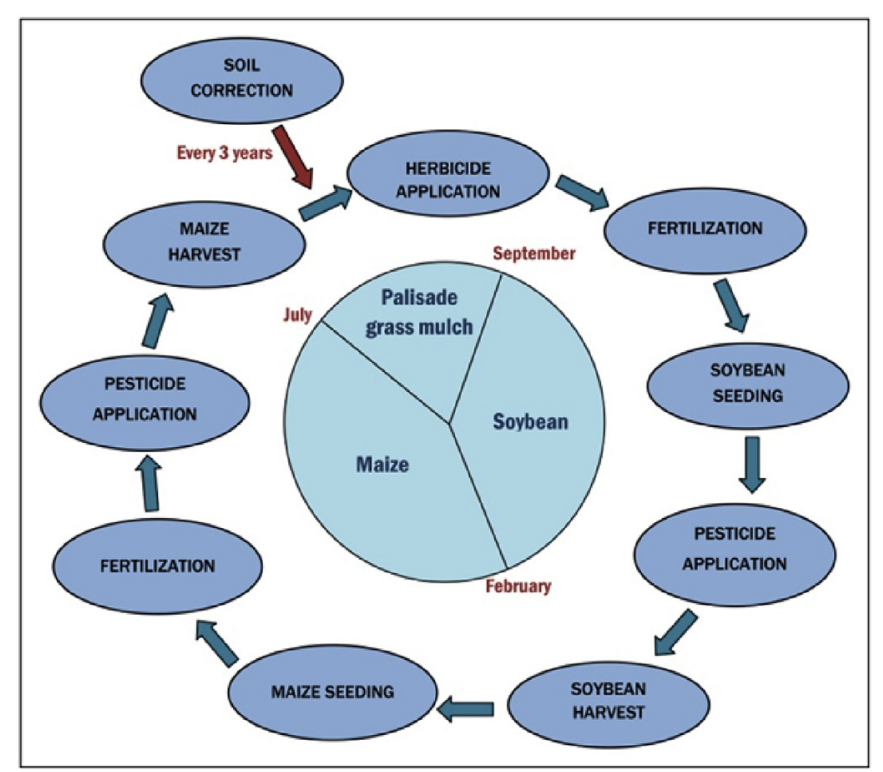

Fig. 3. Soybean-Maize crop system carried out on Farms 4 and 5.

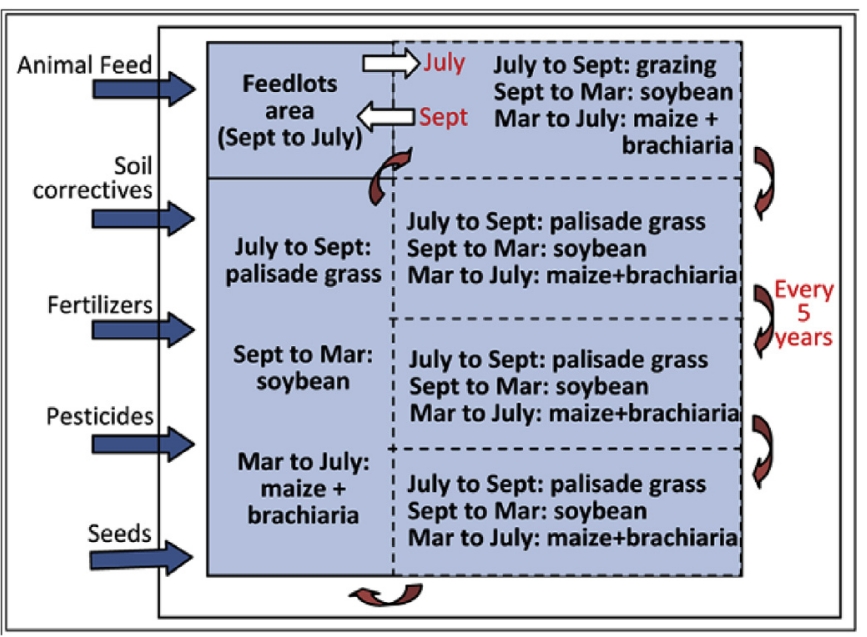

Fig. 4. Integrated crop livestock system carried out on Farm 1. (Rectangle sizes are not proportional to represented areas).

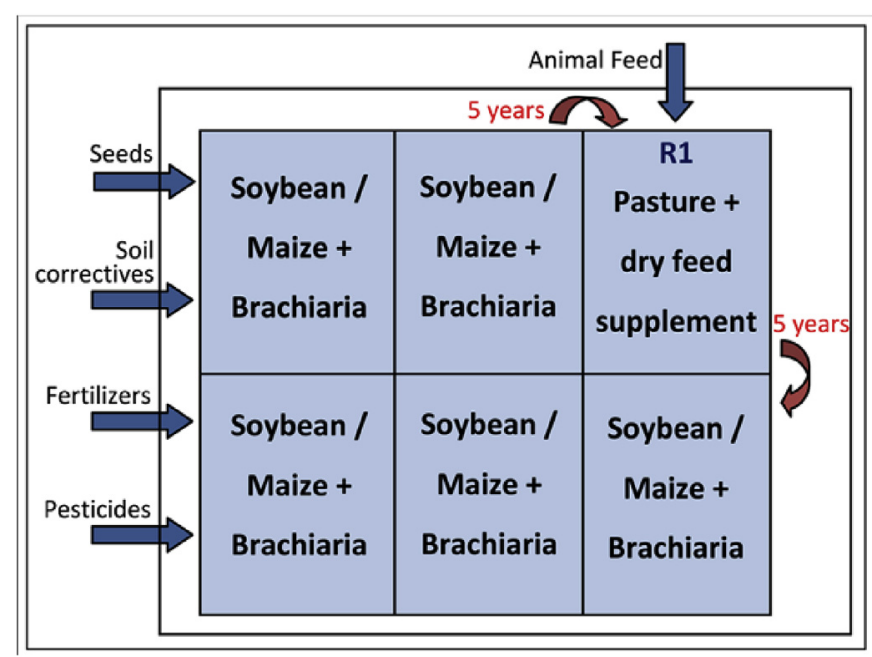

Fig. 5. Integrated crop livestock system carried out on the Farm 2. (Rectangle sizes are not proportional to represented areas).

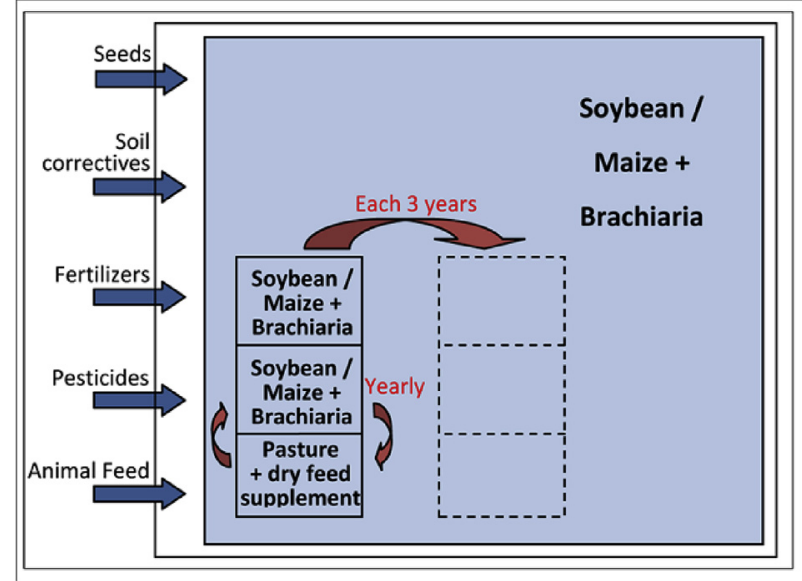

Fig. 6. Integrated crop livestock system carried out on the Farm 3. (Rectangle sizes are not proportional to represented areas).

Table 4

Primary data for cattle fattening period in 2014.

\begin{tabular}{lllll}
\hline & Unit & Farm 1 & Farm 2 & Farm 3 \\
\hline Cattle for slaughter & head & 367 & 1500 & 700 \\
Dry feed & $\mathrm{kg} / \mathrm{d}$ per head & 5.7 & 2.0 & 5.0 \\
fattening period & day & 180.0 & 145.0 & 120.0 \\
Weight gain & $\mathrm{kg} / \mathrm{d}$ per head & 1.1 & 0.9 & 1.2 \\
Total dry feed & $\mathrm{kg} / \mathrm{y}$ & 376,542 & 435,000 & 420,000 \\
Total weight gain & $\mathrm{kg} / \mathrm{y}$ & 72,666 & 195,750 & 100,800 \\
\hline
\end{tabular}

On Farm 3 (Fig. 6), from the whole area used of 5600 ha, 5300 ha is employed to grow soybeans (between October and March) and maize associated with palisade grass (in the inter-season). Palisade grass is used exclusively for soil cover, not for cattle grazing. The remaining area (300 ha) is divided into three paddocks of 100 ha each. One of these is used for grazing with dry feeding in pasture two times a day, like in Farm 2. The other two paddocks are used for regular crops. The separation of the two paddocks used for soybean/maize allows observing the differences in the yields between areas with recent rotation with cattle and other areas with previous rotation. These paddocks are rotated annually. At the end of the third year, three new paddocks are established.

The indicators regarding cattle production used here, with their respective units, are: number of animals slaughtered per year; dry feed consumed, in kilograms per head per day ( $\mathrm{kg} / \mathrm{d}$ per head) in asfed base (13\% moisture content); fattening period in days; and live weight gain in the fattening period, in kilograms per day, as shown in Table 4.

The amounts of concentrated feed necessary to finish cattle in ICLS farms in 2014 was obtained by multiplying daily intake by the number of animals slaughtered and fattening period (Table 4). Data for total weight gain (Table 4) result from multiplying total weight gain per day by the fattening period and by the total number of animals slaughtered in 2014.

This work considers only cattle manure management and enteric emissions, because local cattle finishing systems are brief (around 100 days) with low use of manufactured inputs, The "Reference Report of Agriculture Sector of the Third National Communication of Brazil to the United Nations Framework Convention on Climate Change" (MSTI, 2015) presents 51 and $1.3 \mathrm{~kg}$ $\mathrm{CH}_{4} / \mathrm{y}$ per head for enteric fermentation and manure management emissions for adult animals. These emissions are multiplied by 72 , which is the global warming potential for 20 years $\left(\mathrm{GWP}_{20}\right)$ for 
Table 5

General data and inputs used by the five farms studied in the municipality of Maracajú (MS) in 2014

\begin{tabular}{|c|c|c|c|c|c|c|}
\hline & Units & Farm 1 & Farm 2 & Farm 3 & Farm 4 & Farm 5 \\
\hline \multicolumn{7}{|l|}{ General Data } \\
\hline Soybean area & ha & 2115.05 & 2000 & 5500 & 3000 & 5000 \\
\hline Maize area & ha & 1338.15 & 1800 & 4800 & 3000 & 4800 \\
\hline Cattle area & ha & $10^{\mathrm{a}}$ & 400 & 100 & & \\
\hline Total area & ha & 2125.05 & 2400 & 5600 & 3000 & 5000 \\
\hline Soybean yield & $\mathrm{kg} / \mathrm{ha}$ & 3340.8 & 3300 & 3911 & 3180 & 3900 \\
\hline Maize yield & $\mathrm{kg} / \mathrm{ha}$ & 5810.4 & 6000 & 7225 & 5820 & 5400 \\
\hline \multicolumn{7}{|l|}{ Inputs } \\
\hline Limestone & $\mathrm{kg} / \mathrm{ha}$ & 394.67 & 1000.00 & 833.33 & 333.33 & 1000.00 \\
\hline Gypsum & $\mathrm{kg} / \mathrm{ha}$ & 415.33 & 333.33 & 166.67 & 333.33 & 500.00 \\
\hline Soybean seeds & $\mathrm{kg} / \mathrm{ha}$ & 40.00 & 40.00 & 50.00 & 40.00 & 50.00 \\
\hline Maize seeds & $\mathrm{kg} / \mathrm{ha}$ & 18.00 & 18.00 & 20.00 & 17.00 & 18.00 \\
\hline Brachiaria seeds & $\mathrm{kg} / \mathrm{ha}$ & 2.50 & 4.00 & 3.50 & 2.50 & 2.50 \\
\hline Fertilizer $(\mathrm{N})$ maize & $\mathrm{kg} / \mathrm{ha}$ & 120.00 & 120.00 & 110.64 & 115.00 & 140.00 \\
\hline Fertilizer $(\mathrm{N})$ soy & $\mathrm{kg} / \mathrm{ha}$ & 20.00 & 20.00 & 20.00 & 15.00 & 9.20 \\
\hline Fertilizer $\left(\mathrm{P}_{2} \mathrm{O}_{5}\right)$ soy & $\mathrm{kg} / \mathrm{ha}$ & 100.00 & 100.00 & 100.00 & 95.00 & 90.00 \\
\hline Fertilizer $\left(\mathrm{K}_{2} \mathrm{O}\right)$ soy & $\mathrm{kg} / \mathrm{ha}$ & 225.00 & 250.00 & 200.00 & 150.00 & 140.00 \\
\hline Fungicides soy & $\mathrm{kg} / \mathrm{ha}$ & 0.69 & 2.30 & 3.38 & 1.58 & 0.83 \\
\hline Herbicides soy & $\mathrm{kg} / \mathrm{ha}$ & 17.46 & 13.63 & 17.38 & 17.04 & 20.28 \\
\hline Insecticides soy & $\mathrm{kg} / \mathrm{ha}$ & 0.55 & 1.34 & 0.53 & 0.18 & 0.29 \\
\hline Fungicides maize & $\mathrm{kg} / \mathrm{ha}$ & 2.20 & 0.92 & 0.69 & 1.62 & 1.50 \\
\hline Herbicides maize & $\mathrm{kg} / \mathrm{ha}$ & 3.05 & 1.65 & 1.10 & 2.00 & 2.63 \\
\hline Insecticides maize & $\mathrm{kg} / \mathrm{ha}$ & 0.90 & 0.91 & 0.46 & 0.30 & 0.35 \\
\hline Diesel & $\mathrm{kg} / \mathrm{ha}$ & 70.02 & 63.98 & 124.07 & 40.99 & 25.59 \\
\hline Drying - natural gas & $\mathrm{m}^{3} / \mathrm{ha}$ & 30 & & & & 31.25 \\
\hline Drying - firewood & $\mathrm{m}^{3} / \mathrm{ha}$ & & 0.44 & 0.49 & 0.17 & \\
\hline
\end{tabular}

${ }^{\text {a }}$ Feedlot area, not including area where cattle graze two months in a year.

methane (IPCC, 2007) and divided by 365 to obtain 10.0603 and $0.2564 \mathrm{~kg} \mathrm{CO} 2 \mathrm{eq} / \mathrm{d}$ per head.

Table 5 summarizes information about each farm, including the agricultural inputs per hectare used for agriculture.

\subsubsection{Industrial phases}

In the extraction phase, besides oil, only soybean meal (as a byproduct) is considered. Although soy meal is actually the most valuable product from soybean growing, due to its use as animal feed, it is considered a byproduct of the system since oil is the output used to produce biodiesel. In transesterification, the only byproduct considered is glycerin.

According to Esteves et al. (2016) there is no substantial variation of extraction and transesterification inputs in the course of time. This work uses local industrial data, obtained from companies in the DMR, with values similar to the literature data. Table 6 presents inputs for the local industrial processing of soybeans for each farm studied, proportional to its yield per area.

The conversion factor of $6.329 \mathrm{~kg}$ of soybean for each kilogram of biodiesel was obtained from the quantity of biodiesel produced $(0.158 \mathrm{~kg})$ from $1 \mathrm{~kg}$ of soybean grain, as shown in Table 6.

\subsubsection{Transportation phases}

For transportation of soybean and degummed oil, all oil extraction units and transesterification plants located in the state of Mato Grosso do Sul are considered. Emissions from transport are calculated through average distances from each of the five farms to the crushing units and from these to the biodiesel plants.

The state of Mato Grosso do Sul currently has three soybean crushing mills: Bunge, Correcta and Cargill. To calculate grain transport, road distances, obtained from Google Earth, between each farm and the three mills in Mato Grosso do Sul are used. Based on Esteves et al. (2016), the quantity of soybeans necessary for each of the crushing mills and their location are estimated with the percentage of the crop from DMR going to each of these three facilities. Results indicated that, from total production, $10.39 \%$ goes to Cargill, $0.96 \%$ to Bunge and $1.45 \%$ to Correcta. The rest is exported. Multiplying these percentages by twice the distance between the farms and mills and the total production of soybeans from each farm in 2014 resulted in the total tonne-kilometers (tkm) for each farm. Twice the distance is used because of a conservative assumption that trucks return empty from crushing units (Table 7).

Mato Grosso do Sul has two soybean oil transesterification plants: Cargill and Delta, responsible for $72.5 \%$ and $27.5 \%$ of biodiesel production in the state. The Cargill plant uses an integrated system for crushing and transesterification, so no intermediate transportation is necessary. The soybean oil considered to be transported to Delta was derived from the production of each farm

Table 6

Main inputs and outputs for soybean oil extraction and transesterification in Dourados micro-region, Mato Grosso do Sul state in 2014.

\begin{tabular}{|c|c|c|c|c|c|c|c|}
\hline & & Inputs per $\mathrm{kg}$ of soybean & Farm 1 & Farm 2 & Farm 3 & Farm 4 & Farm 5 \\
\hline & & \multicolumn{6}{|l|}{ per hectare } \\
\hline \multicolumn{8}{|l|}{ Extraction } \\
\hline \multicolumn{8}{|l|}{ Inputs } \\
\hline Soybean yield & $\mathrm{kg} / \mathrm{ha}$ & & 3340.800 & 3300.000 & 3910.909 & 3180.000 & 3900.000 \\
\hline Electricity & kWh & 0.040 & 133.632 & 132.000 & 156.436 & 127.200 & 156.000 \\
\hline Natural gas & $\mathrm{m}^{3}$ & 0.018 & 61.538 & 60.786 & 72.039 & 58.576 & 71.838 \\
\hline Hexane & $\mathrm{kg}$ & 0.001 & 3.976 & 3.927 & 4.654 & 3.784 & 4.641 \\
\hline \multicolumn{8}{|l|}{ Outputs } \\
\hline Soybean oil & $\mathrm{kg}$ & 0.180 & 601.344 & 594.000 & 703.964 & 572.400 & 702.000 \\
\hline Soybean meal & $\mathrm{kg}$ & 0.810 & 2706.048 & 2673.000 & 3167.836 & 2575.800 & 3159.000 \\
\hline \multicolumn{8}{|l|}{ Transesterification } \\
\hline Soybean oil & $\mathrm{kg}$ & 0.180 & 601.344 & 594.000 & 703.964 & 572.400 & 702.000 \\
\hline Firewood & $\mathrm{m}^{3}$ & 0.000 & 0.048 & 0.047 & 0.056 & 0.045 & 0.055 \\
\hline Electricity & kWh & 0.011 & 6.341 & 6.264 & 7.424 & 6.036 & 7.403 \\
\hline Water & $\mathrm{kg}$ & 0.004 & 2.235 & 2.208 & 2.617 & 2.128 & 2.609 \\
\hline Sodium hydroxide & $\mathrm{kg}$ & 0.002 & 1.069 & 1.056 & 1.251 & 1.018 & 1.248 \\
\hline Phosphoric acid & $\mathrm{kg}$ & 0.001 & 0.364 & 0.360 & 0.427 & 0.347 & 0.425 \\
\hline Methanol & $\mathrm{m}^{3}$ & 0.000026 & 0.016 & 0.016 & 0.018 & 0.015 & 0.018 \\
\hline Sodium methylate & $\mathrm{kg}$ & 0.002 & 1.373 & 1.356 & 1.607 & 1.307 & 1.603 \\
\hline Hydrochloric acid & $\mathrm{kg}$ & 0.001 & 0.622 & 0.614 & 0.728 & 0.592 & 0.726 \\
\hline \multicolumn{8}{|l|}{ Outputs } \\
\hline Biodiesel & $\mathrm{kg}$ & 0.158 & 95.127 & 93.965 & 111.360 & 90.548 & 111.050 \\
\hline Crude glycerin & $\mathrm{kg}$ & 0.018 & 11.105 & 10.970 & 13.000 & 10.571 & 12.964 \\
\hline
\end{tabular}


Table 7

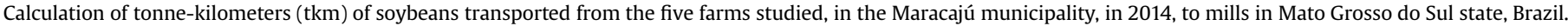

\begin{tabular}{|c|c|c|c|c|c|c|c|c|}
\hline \multirow[t]{2}{*}{$\begin{array}{l}\text { Share of soybeans } \\
\text { used for biodiesel }\end{array}$} & \multirow[t]{2}{*}{$\begin{array}{l}\text { Soybean } \\
\text { production }(\mathrm{t})\end{array}$} & $\begin{array}{l}\text { Distance to } \\
\text { Bunge (km) }\end{array}$ & \multirow[t]{2}{*}{ tkm } & \multirow{2}{*}{$\begin{array}{l}\begin{array}{l}\text { Distance to } \\
\text { Correcta }(\mathrm{km})\end{array} \\
1.45 \%\end{array}$} & \multirow[t]{2}{*}{ tkm } & $\begin{array}{l}\text { Distance to } \\
\text { Cargil }(\mathrm{km})\end{array}$ & \multirow[t]{2}{*}{$\mathrm{tkm}$} & \multirow[t]{2}{*}{ Total tkm } \\
\hline & & $0.96 \%$ & & & & $10.39 \%$ & & \\
\hline Farm 1 & 7066 & 252 & 17,094 & 268 & 27,458 & 1022 & 750,305 & 794,857 \\
\hline Farm 2 & 6600 & 260 & 16,474 & 304 & 29,093 & 1028 & 704,941 & 750,507 \\
\hline Farm 3 & 21,510 & 350 & 72,274 & 338 & 105,421 & 1032 & $2,306,405$ & $2,484,100$ \\
\hline Farm 4 & 9540 & 324 & 29,673 & 444 & 61,419 & 944 & 935,698 & $1,026,790$ \\
\hline Farm 5 & 19,500 & 242 & 45,302 & 222 & 62,771 & 1020 & $2,066,571$ & $2,174,644$ \\
\hline
\end{tabular}

Table 8

Calculation of tonne-kilometers (tkm) for transport of degummed oil from crushing to transesterification units in Mato Grosso do Sul state, Brazil.

\begin{tabular}{|c|c|c|c|c|c|c|c|c|c|c|}
\hline \multirow{3}{*}{$\begin{array}{l}\text { Share of soybeans } \\
\text { used for biodiesel }\end{array}$} & \multirow{3}{*}{$\begin{array}{l}\text { Soybean } \\
\text { Production (t) }\end{array}$} & \multirow[t]{3}{*}{ Oil Production $(t)$} & \multirow{3}{*}{$\begin{array}{l}\text { Soybean Oil } \\
\text { for Delta }(t)\end{array}$} & \multicolumn{3}{|c|}{ Bunge-Delta } & \multicolumn{3}{|c|}{ Correcta-Delta } & \multirow[t]{3}{*}{ Total tkm } \\
\hline & & & & Oil (t) & Distance $(\mathrm{km})$ & tkm & Oil (t) & Distance $(\mathrm{km})$ & tkm & \\
\hline & & & & & & $0.96 \%$ & & & $1.45 \%$ & \\
\hline Farm 1 & 7066 & 1272 & 350.2 & 140.1 & 178.4 & 239.9 & 210.1 & 424 & 1291.9 & 1531.84 \\
\hline Farm 2 & 6600 & 1188 & 327.1 & 130.9 & 178.4 & 224.1 & 196.3 & 424 & 1206.7 & 1430.82 \\
\hline Farm 3 & 21,510 & 3872 & 1066.1 & 426.5 & 178.4 & 730.4 & 639.7 & 424 & 3932.8 & 4663.18 \\
\hline Farm 4 & 9540 & 1717 & 472.9 & 189.1 & 178.4 & 323.9 & 283.7 & 424 & 1744.3 & 2068.19 \\
\hline Farm 5 & 19,500 & 3510 & 966.5 & 386.6 & 178.4 & 662.1 & 579.9 & 424 & 3565.3 & 4227.43 \\
\hline
\end{tabular}

studied. According to Delta, oil percentages taken from the Bunge and Correcta crushing mills to the Delta plant are $40 \%$ and $60 \%$, respectively. Again, the distances were multiplied by two since trucks were assumed to return empty (Table 8).

\section{Results and discussion}

This section presents the results of the assessment with the respective discussion. Detailed calculations that led to these results are demonstrated in the tables available in the Supplementary Material.

\subsection{Farming phase emissions using sub-processes division (SD)}

Following the SD approach, only agricultural inputs directly applied to soybean farming were counted, excluding inputs directly related to maize and beef (LWG) production. See Supplementary Material - Table A2.

It should be noted that the SD approach might not be adequate for the circumstances of the systems analyzed here, since it eliminates the effect of interactions among farming activities. In order to allow comparisons with other studies, this study performed calculations and present the results using this approach.

Fig. 7 shows farming emissions using the SD approach for the two functional units considered (kilogram $\mathrm{CO}_{2}$ eq per hectare cultivated with soybeans and kilogram $\mathrm{CO}_{2} \mathrm{eq}$ per kilogram of biodiesel obtained).

To calculate total emissions per hectare, the emissions factor of each input is multiplied by the amount of the given input per hectare. To calculate emissions per kilogram of biodiesel, after multiplying the emission factor by the amount applied per hectare, the result is divided by the soybean yield obtained per hectare and then multiplied by the biodiesel yield factor from soybean, i.e., $6.329 \mathrm{~kg}$ of soybean per $\mathrm{kg}$ of biodiesel. This relation was obtained from primary industrial data (Supplementary Material - Table A1). The inventory contains annual quantities of limestone, gypsum and diesel applied to produce both soybeans and maize (Table 5). For this reason, to calculate the emissions from the soybean cultivation sub-process, half of these inputs were considered.

The results show that Farm 5 had the lowest emission per hectare, due to the smaller amount of nitrogen fertilizer applied, representing $73 \mathrm{~kg} \mathrm{CO} 2 \mathrm{eq} /$ ha less than Farms 1,2 and 3 (Supplementary Material - Table A2). Despite the relatively lower use of inputs, this farm had the second largest yield, demonstrating high farming efficiency in the use of external inputs. However, high yields alone do not represent lower impacts, once higher yields tend to demand larger amounts of inputs. For example, Farm 3, which has the highest yield (Table 5) but uses large amounts of nitrogen for soybeans, has the largest emissions related to soybean cultivation. In fact, soybean cultivation does not demand $\mathrm{N}$
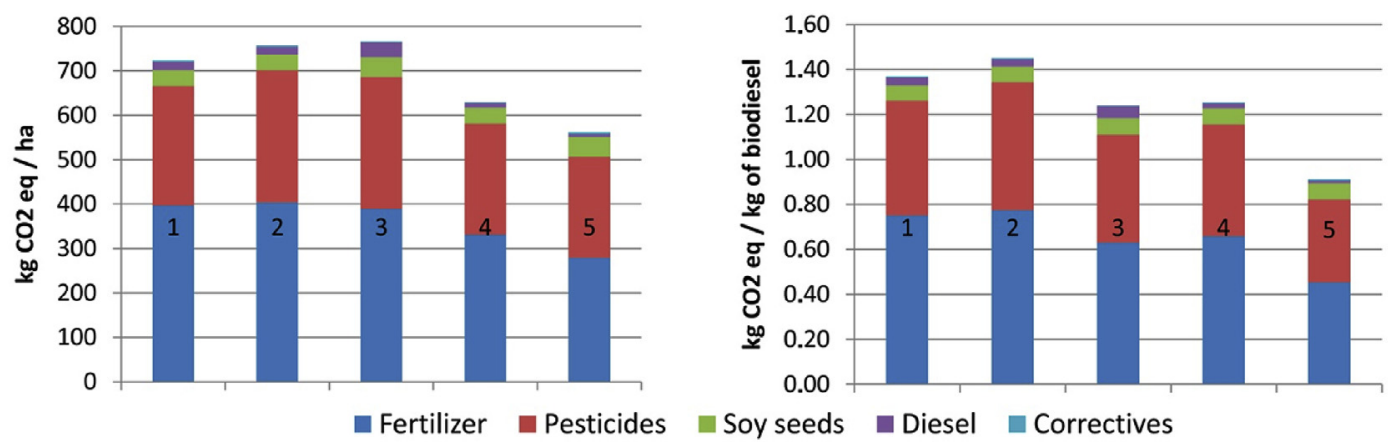

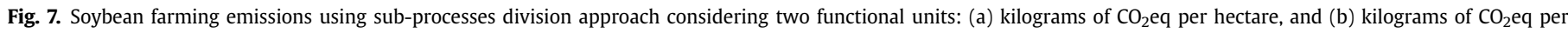
kilogram of biodiesel. 
fertilization due to symbiotic fixation. Phosphorous, on the other hand, is mandatory. Since nitrogen is part of the fertilizer monoammonium phosphate (MAP), which is a cheap source of $\mathrm{P}$, nitrogen ends up being used, implying unnecessary impacts from additional $\mathrm{N}$ source.

When considering emissions per kilogram of biodiesel instead of emissions per hectare, the general ranking of the farms does not change, except for Farm 3, which has the second lowest emissions due to its high soybean yields.

\subsection{Farming phase emissions using system expansion (SE)}

Under the system expansion approach, emissions related to avoided products (maize and beef-LWG) are subtracted from the total emissions from all the inputs used for soybeans, maize and LWG in each farm. This approach is more appropriate for integrated farming systems, once these systems are based on a strong relationship and exchange of benefits among the different farming activities. This relationship cannot be simply separated, attributing a unanimously accepted division of the total inputs for each of the farming processes involved.

Brazil and the USA are largest global producers of maize and beef cattle. Emissions related to maize avoided were calculated using the pre-existing process in the Ecoinvent 3.0 database "Global Maize Grain Production", which results in $0.574 \mathrm{~kg} \mathrm{CO}_{2} \mathrm{eq} / \mathrm{kg}$ of maize (Supplementary Material - Table A3). In this process, 30\% of the impact comes from the energy in fuel that powers farm machinery.

Regarding cattle production, Dudley et al. (2014) and Cerri et al. (2016) calculated the carbon footprint of farms in the USA and Brazil, respectively. The American study used data from feedlot farming, the major process for cattle finishing in the USA. The Brazilian study, on the other hand, considered grazing systems with agricultural inputs. Despite different husbandry systems, results from both studies are close to each other: $8.2 \mathrm{~kg}$ of $\mathrm{CO}_{2}$ equivalent per kilogram of LWG ( $\mathrm{kg} \mathrm{CO} \mathrm{CO}_{2} \mathrm{eq} / \mathrm{kg}$ LWG) in the USA and $6.4 \mathrm{~kg}$ $\mathrm{CO}_{2} \mathrm{eq} / \mathrm{kg}$ LWG in Brazil. In this study, emissions from avoided product LWG were assumed to be the average of the above mentioned values $\left(7.275 \mathrm{~kg} \mathrm{CO} \mathrm{CO}_{2} \mathrm{eq} / \mathrm{kg}\right.$ LWG), as presented in Table A3 of the Supplementary Material.

Comparative results of emissions for all farms using the SE approach are presented in Fig. 8 considering both functional units kilogram of $\mathrm{CO}_{2} \mathrm{eq}$ per hectare cultivated and per kilogram of biodiesel processed. Details can be found in Supplementary Material - Table A3. In the calculations considering emissions per hectare, the emission factor of each input is multiplied by the amount applied per hectare and then by the crop area (soybean or maize), finally dividing by the total area under cultivation. To calculate emissions per kilogram of biodiesel, the product of multiplying the emissions factor by the total amount applied per hectare is divided by the respective soybean yield. As in the SD approach, this result is finally multiplied by the ratio between soybean grain and biodiesel $(6.329 \mathrm{~kg}$ of soybean per $\mathrm{kg}$ of biodiesel).

For both functional units, all farms investigated presented negative GHG emissions results, meaning a net benefit for the environment. This happens because avoided emissions from maize and LWG production from these systems more than offset emissions from all inputs necessary to obtain these co-products.

In integrated agropastoral systems, one process favors the other, especially through weed reduction, pest management and residual fertilization, making it difficult to isolate each process in the study. Integrated processes reduce atmospheric emissions by avoiding use of inputs to produce these outputs by isolated conventional farming systems adopted somewhere else. In the case of maize, especially when combined with palisade grass, the crop itself and straw left on the field suppress weed growth, and later serve as important soil cover for no-till planting of soybeans. No-till systems avoid erosion and conserve water in the soil much longer than traditional systems, favoring the next soybeans crop. Also, although difficult to measure, the presence of residual fertilizer after growing soybeans, benefits maize, which does not happen in single cultivation systems. The same is true for weed and pest control (Supplementary Material - Tables A2 and A3). In the conventional systems maize follows a fallow winter, with some nitrogen loss. This makes fertilizer use more efficient, through maize being planted immediately after the soybean harvest, benefiting, from residual soy fertilizers besides the good benefits from no-till, improving, for example, water retention i.e. soil moisture.

Along with crop interactions, producing maize in the soybeans inter-season reduces total impact of inputs per hectare cultivated, since maize yields are about twice that of soybeans (6000 vs. $3000 \mathrm{~kg} / \mathrm{ha}$ ), with maize also using less pesticides than soybeans.

The impact of grain drying, although having small relevance in the total impacts, is higher for the three farms using firewood (Farms 2, 3 and 4) than those burning natural gas (Farms 1 and 5).
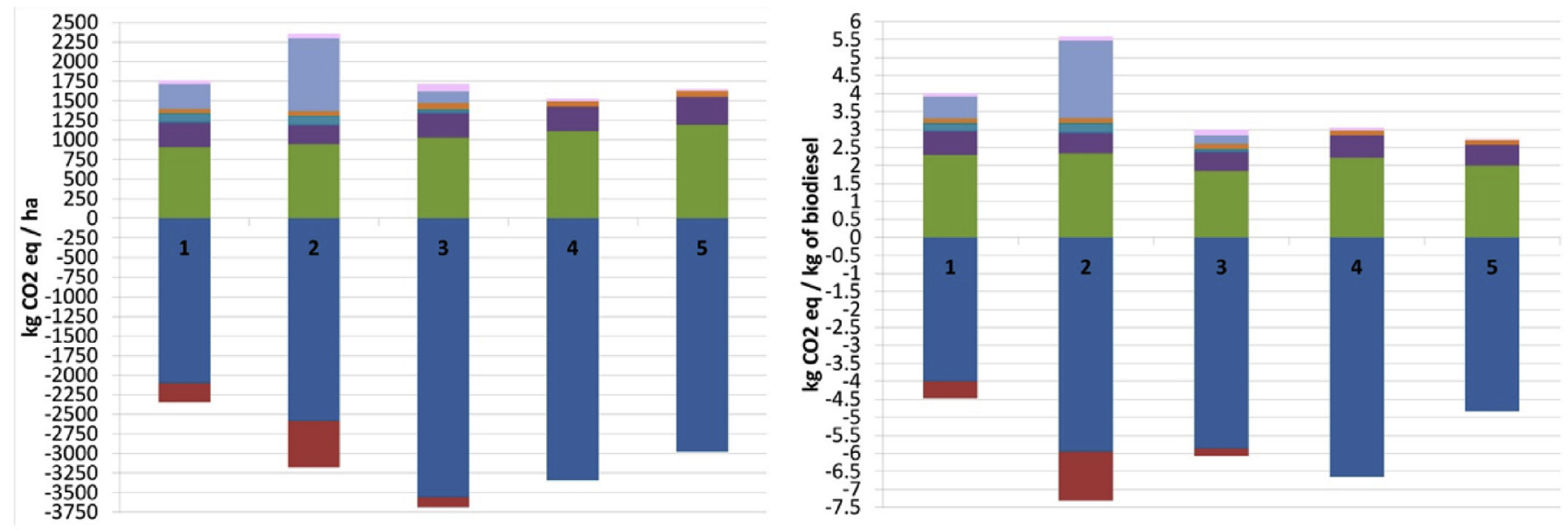

Maize (avoided) $\square$ Cattle head (avoided) $\square$ Fertilizer $\square$ Pesticides $\square$ Animal feed $\square$ Seeds $\square$ Enteric Fermentation and Manure Management $\square$ Other

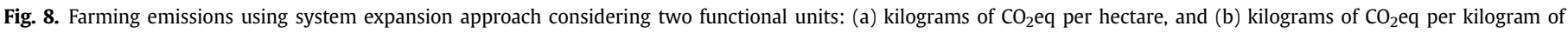
biodiesel. 
Gas heating for drying causes less atmospheric impact than burning firewood.

Considering the SE approach, the emissions per hectare are directly and negatively related to maize yield, i.e., the higher the productivity, the lower the final emissions of the farming phase. Under this approach, maize produced in a given system avoids production maize somewhere else. These avoided emissions compensate emissions from the studied farms. Ranking the farms in rising order of final net emissions per hectare, Farm 3 has the lowest emissions, followed by Farms 4, 2, 5 and 1. By the same approach but analyzing results per kilogram of biodiesel obtained, a direct relation of emissions with the ratio between maize/soybean production in each farm was observed: the larger the maize/soybean ratio, the lower the emissions. Thus, in rising order of emissions per $\mathrm{kg}$ of biodiesel obtained, there was a change in the ranking, with Farm 4 having the lowest final emissions (maize/ soybean ratio of 1.83), followed by Farms 3, 2, 5 and 1.

Of the ICLS farms studied, Farm 1 presents the worst result for emissions for both apportionments and both functional units adopted. This farm is the only one of the three using ICLS that both breeds and fattens cattle, although here the emissions are only computed from the fattening period. The animals of this farm have longer to fatten (180 days), and this farm requires larger amounts of feedlot inputs. This proportionally increases emissions from enteric fermentation and manure management per unit of LWG produced. Furthermore, Farm 1 has lower maize yield (Table 5), despite applying equivalent quantities of inputs per hectare, leading to total emissions from inputs similar to those of the other farms, and much lower emissions avoided than any of the other farms (Supplementary Material - Table A3).

Finally, Farm 3 shows the best results among ICLS farms. It uses dry feed in pastures like Farm 2, but performs more frequent rotation of grazing areas. Besides better cattle performance, Farm 3 shows the highest soybean and maize yields. Farms 2 and 3 show similar total avoided impact, even though Farm 3 is more oriented to crop farming while Farm 2 is more dedicated to cattle breeding. This shows that variations among ICLS are not necessarily linked to GHG emissions, leaving some room for farmers to choose production goals that better suit their needs without losing environmental efficiency.

For GHG emissions caused by biodiesel production, there was no substantial difference among farms using or not using ICLS. The benefit is the production of more products, especially food, from the same area, which can account for avoided emissions. Producing maize in the inter-season, independently from cattle, actually has the largest beneficial impact.

Despite the relatively small area used for cattle farming, three farms, on the study, use ICLS. The study region is characterized by a tendency of animal confinement, as evidenced by the growth of cattle stocking rate (Esteves et al., 2017) and large replacement of pastures by crop areas (Esteves et al., 2016).
In this context, integrating crop farming with cattle husbandry seems to be the best option for optimizing land use. The study used cattle farming with different levels of intensification (grain feeding in pastures, feedlots etc.) in order to obtain beef, a traditional global commodity from this area. At the same time, it accounts for expansion of soybean farming, another commodity with a strong potential also as biofuel.

The benefit is the production of more products, especially food, from the same area, which can account for avoided emissions. Producing maize in the inter-season, independently from cattle, actually has the largest beneficial impact.

\subsection{Total emission results}

Details of calculations regarding emissions from the processing phases are shown in Supplementary Material - Table A6. Emissions per hectare from the industrial phases were obtained by multiplying emissions factor by the soybean yield for each farm and by the amounts of inputs for each kilogram of soybeans produced (Supplementary Material - Table A6).

Calculations of emissions per kilogram of biodiesel was obtained by multiplying the emissions factors by the inputs per kilogram of biodiesel produced (Supplementary Material- Table A1).

Calculations for emissions from transport are detailed in Supplementary Material-Tables A4 and A5. Emissions per hectare were obtained by dividing total emissions (obtained by multiplying the emission factor by the total tkm) by the total area of each farm. Emissions per kilogram of biodiesel were obtained by dividing the emissions per hectare by the ratio between kilograms of biodiesel and kilograms of soybeans, and by the soybean yield.

Table 9 presents biodiesel production emissions per hectare of soybeans produced. Each phase of the process considered the allocation factors calculated as shown in Section 2.2.2.

Table 10 presents biodiesel production emissions per kilogram of biodiesel produced considering the different allocation factors for each phase. The emissions per kilogram of biodiesel for the industrial and transport phases did not vary by farm, since the emissions do not depend on the farms' productivity levels.

Independently of the approach adopted (SD or SE) and regardless of the functional unit used for comparison (emissions per hectare or per kilogram of biodiesel obtained), the farming phase alone was responsible for around $52 \%$ of the total emissions. Transesterification accounted for about 34\% of total emissions, followed by oil extraction (10\%) and soybean grain transport (4\%).

Oil transport is the individual process with the lowest impact on the entire production chain, even though the transesterification allocation factor considers almost all oil to be transported for biodiesel production. Specifically for this study, the low impact is due to the large amount of oil whose transport was avoided by Cargill's integrated process in a single plant.

Table 9

Total emissions from soybean biodiesel ( $\mathrm{kg} \mathrm{CO}$ eq/ha) from the study of five farms in Maracajú, MS in 2014.

\begin{tabular}{|c|c|c|c|c|c|c|}
\hline & Allocation Factor & Farm 1 & Farm 2 & Farm 3 & Farm 4 & Farm 5 \\
\hline \multicolumn{7}{|l|}{ Emissions (kg CO $2 \mathrm{eq} / \mathrm{ha})$} \\
\hline SD farming emissions & $25.5 \%$ & 182.34 & 179.45 & 194.78 & 163.23 & 161.08 \\
\hline SE farming emissions & $25.5 \%$ & -149.98 & -210.25 & -502.29 & -461.92 & -338.25 \\
\hline Grain transport emissions & $25.5 \%$ & 15.52 & 15.50 & 18.66 & 14.14 & 17.97 \\
\hline Extraction emissions & $25.5 \%$ & 38.74 & 38.27 & 45.35 & 36.87 & 45.22 \\
\hline Oil transport emissions & $94.6 \%$ & 0.11 & 0.11 & 0.13 & 0.11 & 0.13 \\
\hline Transesterification emissions & $94.6 \%$ & 134.05 & 132.41 & 156.92 & 127.60 & 156.49 \\
\hline SD total emissions & & 370.76 & 365.74 & 415.84 & 341.95 & 380.89 \\
\hline SE total emissions & & 38.45 & -23.96 & -281.23 & -283.20 & -118.44 \\
\hline
\end{tabular}

SD - sub-processes division; SE - system expansion. 
Table 10

Total soybean biodiesel emissions ( $\mathrm{kg} \mathrm{CO} 2 \mathrm{eq} / \mathrm{kg}$ of biodiesel) from the study of five farms in Maracajú, MS in 2014.

\begin{tabular}{llllll}
\hline & Allocation Factor & Farm 1 & Farm 2 & Farm 3 & Farm 4 \\
\hline Emissions (kg CO 2 eq/kg of biodiesel) & & & & & \\
SD farming emissions & $25.5 \%$ & 0.345 & 0.344 & 0.315 & 0.325 \\
SE farming emissions & $25.5 \%$ & -0.119 & -0.440 & -0.784 & -0.919 \\
Grain transport emissions & $25.5 \%$ & 0.029 & 0.030 & 0.030 & 0.028 \\
Extraction emissions & $25.5 \%$ & 0.073 & 0.073 & 0.073 & 0.073 \\
Oil transport emissions & $94.6 \%$ & 0.000 & 0.000 & 0.000 & 0.000 \\
Transesterification emissions & $94.6 \%$ & 0.254 & 0.254 & 0.254 & 0.254 \\
\hline SD total emissions & & 0.702 & 0.701 & 0.073 & 0.673 \\
SE total emissions & & 0.238 & -0.082 & -0.427 & 0.681 \\
\hline
\end{tabular}

SD - sub-processes division; SE - system expansion.

The impact of the oil extraction phase is due to the energy spent in the process, which is responsible for more than $70 \%$ of the impact of this phase (Supplementary Material - Table A6).

In transesterification, methanol is the input responsible for almost half the emissions volume. This impact is connected to the fossil origin of this product. It is advisable to analyze the possibility of using other alcohols, such as sugarcane ethanol, to minimize GHG emissions from the industrial phase (Supplementary material-Table A6).

\section{Conclusions}

This study was based on primary data supplied by the producers. To better explain the GHG emissions variations due to the different types of land management, it is necessary to evaluate these aspects under different approaches and functional units. Assessing integrated systems posed a much greater challenge than traditional soybeans/maize faming due to a broader range of systems adopted in the region. More studies, including those to establish evaluation methods for ICLS, are recommended.

Results from this work, solely regarding biodiesel, indicated there is no substantial difference between ICLS and traditional soybean farms. Therefore, biodiesel production is mainly impacted by the frequency of rotations (pasture/crop) and type of management of agricultural system.

Based on the system expansion approach (including emissions from maize and cattle life weight gain) and the mean of the energy, mass and market value allocation factors, the emissions of the farms studied ranged from 38.45 to $-283.20 \mathrm{~kg} \mathrm{CO} 2 \mathrm{eq}$ per hectare and from 0.238 to $-0.564 \mathrm{~kg} \mathrm{CO} \mathrm{CO}_{2} \mathrm{eq}$ per kilogram of biodiesel produced.

The five farms studied produced net benefits to the environment regarding GHG emissions. Most of these are due to maize obtained between soybean crops in all farms, as well as the beefLWG produced by farms using ICLS. The farms avoid emissions from conventional production of these avoided products elsewhere.

Since industrial processes for soybean biodiesel production have not shown substantial improvements in the last decade, with small chances of change in the near future, focusing on improved farming systems is crucial to reduce GHG emissions from biodiesel production. Beside this, farming phase, independent of the approach and functional unit used, was responsible for more than $50 \%$ of the total impact. In this scenario, this work shows that integrated crop livestock system, allows recovering degraded pastures using crops, optimizing farming land use for both activities, with economic and environmental benefits, compensating not only emissions from soybean biodiesel farming phase, but also from its industrial processes.

\section{Acknowledgements}

Grant from CNPq no. 404778/2013-5 is gratefully acknowledged. Elisa M.M. Esteves acknowledges funding from the ANP and CAPES, Brazil.

\section{Appendix A. Supplementary data}

Supplementary data related to this article can be found at https://doi.org/10.1016/j.jclepro.2017.12.262.

\section{References}

ABIOVE, 2017. Brazilian Association of Vegetable Oil Industries. Available at: www. abiove.org.br/site/index.php?page=estatistica\&area=NCOyLTE (accessed: 24.09.17.).

Albarelli, J.Q., Santos, D.T., Holanda, M.R., 2011. Energetic and economic evaluation of waste glycerol cogeneration. Braz. J. Chem. Eng. 28 (4), 691-698. https:// doi.org/10.1590/S0104-66322011000400014.

Balbino, L.C., Cordeiro, A.M.C., de Oliveira, P., Kluthcouski, J., Galerani, P.R., Vilela, L. 2012 (In Portuguese). Informações Agronômicas. Sustainable Agriculture through Integrated Crop-livestock-forest (ICLF), 138. International Plant Nutrition Institute (IPNI), pp. 1-18. Available at: www.ipni.net/PUBLICATION/IABRASIL.NSF/0/67E9CCA96D48CF6685257A84004F5D7D/\$FILE/IA-2012-138.pdf (accessed: 15.08.16.).

Balbino, L.C., Kichel, A.N., Bungenstab, D.J., Almeida, R.G., 2014. Integrated systems: what they are, their advantages and limitations (Org.). In: Bungenstab, D.J. Almeida, R.G. (Eds.), Integrated Crop-livestock-forestry Systems, a Brazilian Experience for Sustainable Farming. 1ed, vol. 1. Embrapa, Brasília, DF, pp. 11-18.

Brondani, M., Hoffman, R., Mayer, F.D., Kleinert, J.S., 2015. Environmental and energy analysis of biodiesel production in Rio Grande do Sul. Brazil. Clean Technol. Envir. 17 (1), 129-143. https://doi.org/10.1007/s10098-014-0768-x.

Cavalett, O., Ortega, E., 2010. Integrated environmental assessment of biodiesel production from soybean in Brazil. J. Clean. Prod. 18, 55-70. https://doi.org/ 10.1016/j.jclepro.2009.09.008.

Cerri, C.C., Silva Moreira, C., Alves, P.A., Raucci, G.S., Castigioni, B. de A., Mello, F.F.C., Cerri, D.G.P., Cerri, C.E.P., 2016. Assessing the carbon footprint of beef cattle in Brazil: a case study with 22 farms in the state of Mato Grosso. J. Clean. Prod. 112, 2593-2600. https://doi.org/10.1016/j.jclepro.2015.10.072.

Cobucci, T., Wruck, F.J., Kluthcouski, J., Muniz, L.C., Martha Jr., G.B., Carvevalli, R.A., Teixeira, S.R., Machado, A.A., Teixeira Neto, M.L., 2007. Options for croplivestock integration and some of its economic aspects (in Portuguese). Inf. Agropecu. (Belo Horiz.) 28, 64-79. Available at: https://www.embrapa.br/ busca-de-publicacoes/-/publicacao/215859/opcoes-de-integracao-lavourapecuaria-e-alguns-de-seus-aspectos-economicos (accessed: 15.08.16.).

CONAB, 2015. National Supply Company (In Portuguese). Available at: http://www. conab.gov.br/conteudos.php? $\mathrm{a}=1252 \& \mathrm{t}=\&$ Paginaobjcmsconteudos $=3 \# \mathrm{~A}$ (accessed: 30.11.16.)

CRCPBAF, 2016. Family Farms Reference Center for Biofuel Production (In Portuguese). Available at: http://www.biomercado.com.br/cotacoes.php (accessed: 30.11.16.).

Dudley, Q., Liska, A., Watson, A., Erickson, G., 2014. Uncertainties in life cycle greenhouse gas emissions from U.S. beef cattle. J. Clean. Prod. 75, 31-39. https://doi.org/10.1016/j.jclepro.2014.03.087.

Esteves, V.P.P., Esteves, E.M.M., Bungenstab, D.J., Loebmann, D.G.S.W., Victoria, D.C., Vicente, L.E., Araujo, O.Q.F., Morgado, C.R.V., 2016. Land use change (LUC) analysis and life cycle assessment (LCA) of Brazilian soybean biodiesel. Clean Techn. Envir. 18, 1655-1673. https://doi.org/10.1007/s10098-016-1161-8, 2016.

Esteves, V.P.P., Esteves, E.M.M., Bungenstab, D.J., Feijó, G.L.D., Araújo, O.D.Q.F., Morgado, C.R.V., 2017. Assessment of greenhouse gases (GHG) emissions from the tallow biodiesel production chain including land use change (LUC). J. Clean. 
Prod. 151, 578-591. https://doi.org/10.1016/j.jclepro.2017.03.063.

FAS/USDA, 2016. Foreign Agricultural Service/United States. Department of Agriculture. Livestock and Poultry: World Markets and Trade. October 2016. Available at: https://apps.fas.usda.gov/psdonline/circulars/livestock_poultry.pdf (accessed: 23.03.17)

Figueiredo, E.B., Jayasundara, S., Bordonal, R.O., Berchielli, T.T., Reis, R.A., WagnerRiddle, C., La Scala Jr., N., 2017. Greenhouse gas balance and carbon footprint of beef cattle in three contrasting pasture-management systems in Brazil. J. Clean. Prod. 142, 420-431. https://doi.org/10.1016/j.jclepro.2016.03.132.

Franzluebbers, A.J., Stuedemann, J.A., 2014. Crop and cattle production responses to tillage and cover crop management in an integrated crop-livestock system in the southeastern USA. Eur. J. Agron. 57, 62-70. https://doi.org/10.1016/ j.eja.2013.05.009.

German, L., Schoneveld, G.C., Pacheco, P., 2011. The social and environmental impacts of biofuel feedstock cultivation: evidence from multi-site research in the forest frontier. Ecol. Soc. 16 (3), 24. https://doi.org/10.5751/ES-04309-160324.

Gil, J., Siebold, M., Berger, T., 2015. Adoption and development of integrated crop-livestock-forestry systems in Mato Grosso Brazil. Agric. Ecosyst. Environ. 199, 394-406. https://doi.org/10.1016/j.agee.2014.10.008.

Hausman, C., 2012. Biofuels and land use change: sugarcane and soybean acreage response in Brazil. Environ. Resour. Econ. 51, 163-187. https://doi.org/10.1007/ s10640-011-9493-7.

Horne, R.E., Matthews, R., 2004. BIOMITRE Technical Manual. Farnham, Surrey, UK. www.globalbioenergy.org/uploads/media/0411_BIOMITRE_Technical_Manual. pdf (accessed: 03.11.16.).

INMET - National Institute of Meteorology, 2014. Available at: http://www.inmet. gov.br/portal/ (accessed: 05.12.14.).

IPCC, 2007. Intergovernmental Panel on climate change. Climate Change 2007. In: The Physical Science Basis. Contribution of Working Group I to the Fourth Assessment Report of IPCC. Available at: http://www.ipcc.ch/pdf/assessmentreport/ar4/wg1/ar4_wg1_full_report.pdf (accessed: 22.06.16.).

ISO, 2006. Environmental Management - Life Cycle Assessment - Requirements and Guidelines. ISO 14044. International Standardization Organization, Geneva, Switzerland. Available at: www.iso.org/standard/38498.html (accessed: 22.06.16.).

Kichel, A.N., Costa, J.A.A., Almeida, R.G., 2011. Advantages of crop-livestock integration in the recovery of degraded pastures (in Portuguese). In: First Mato Grosso Symposium on Beef Cattle. Available at: http://docs.wixstatic.com/ugd/ ae91df_de81a1e9e74f4d0683054649f9ba8144.pdf (accessed: 14.11.16.).

Lemaire, G., Franzluebbers, A., Carvalho, P.C.F., Dedieu, B., 2014. Integrated crop-livestock systems: strategies to achieve synergy between agricultural production and environmental quality. Agric. Ecosyst. Environ. 190, 4-8. https://doi.org/10.1016/j.agee.2013.08.009.

Lin, T., Rodriguez, L.F., Shastri, Y.N., Hansen, A.C., Ting, G.K.C., 2014. Integrated strategic and tactical biomass-biofuel supply chain optimization. Bioresour. Technol. 156, 256-266. https://doi.org/10.1016/j.biortech.2013.12.121.

Marzullo, R.C.M., 2007. Ecoefficiency Analysis of Vegetable Oils from Soybean and Palm, Aiming the Production of Biodiesel (In Portuguese). Dissertation (Master in Engineering). University of São Paulo. Available at: http://www.teses.usp.br/ teses/disponiveis/3/3137/tde-09012008-155336/pt-br.php (accessed: 20.03.2017).

MME, 2015. Mines and Energy Ministry. Monthly Report of Renewable Fuels. Ed. 84, January, 2015 (In Portuguese), Available at: http://www.mme.gov.br/ documents/1138769/1732805/Boletim $+\mathrm{DCR}+\mathrm{n} \% \mathrm{C} 2 \% \mathrm{BA}+84+-$

+janeiro+de+2015.pdf/4dfad41a-4cbb-47c1-99ad-2dc19ce80744 (accessed: 24.03.17.).

MME, 2016. Mines and Energy Ministry. Monthly Report of Renewable Fuels. Ed. 104, October, 2016 (In Portuguese), Available at: http://www.mme.gov.br/
documents/10584/3342640/Boletim+DBio+n\%C2\% BA+104+outubro+de+2016.pdf/40240778-7e81-4ccd-b927-5d0477aadeba (accessed: 30.11.16.).

Moraes, A., Carvalho, P.C.F., Lustosa, S.B.C., Lang, C.R., Deiss, L., 2014. Research on integrated crop-livestock systems in Brazil. Rev. Cienc. Agron. 45, 1024-1031. https://doi.org/10.1590/S1806-66902014000500018.

Mourad, A.L., Walter, A., 2011. The energy balance of soybean biodiesel in Brazil: a case article. Biofuel Bioprod. Bior. 5, 185-197. https://doi.org/10.1002/bbb.278.

MSTI, 2015. Reference Report of Methane Emissions from Enteric Fermentation and Manure Management of Agriculture Sector of Third National Communication of Brazil to the United Nations Framework Convention on Climate Change. Ministry of Science, Technology and Innovation (In Portuguese), Brazil, Brasilia.

Paolotti, L., Boggia, A., Castellini, C., Rocchi, L., Rosati, A., 2016. Combining livestock and tree crops to improve sustainability in agriculture: a case study using the Life Cycle Assessment (LCA) approach. J. Clean. Prod. 131, 351-363. https:// doi.org/10.1016/j.jclepro.2016.05.024.

Pariz, C.M., Costa, C., Crusiol, C.A.C., Castilhos, A.M., Meirelles, P.R.L., Roça, R.O. Pinheiro, R.S.B., Kuwahara, F.A., Martello, J.M., Cavasano, F.A., Yasuoka, J.I., Sarto, J.R.W., Melo, V.F.P., Franzluebbers, A.J., 2017. Lamb production responses to grass grazing in a companion crop system with corn silage and over sowing of yellow oat in a tropical region. Agric. Syst. 151, 1-11. https://doi.org/10.1016/ j.agsy.2016.11.004.

Patzek, T.W., 2009. A first law thermodynamic analysis of biodiesel production from soybean. B. Sci. Technol. Soc. 29 (3), 194-204.

Peters, J., Thielmann, S., 2008. Promoting biofuels: implications for developing countries. Energy Pol. 36, 1538-1544. https://doi.org/10.1016 j.enpol.2008.01.013.

Rajaeifar, M.A., Ghobadian, B., Safa, M., Heidari, M.D., 2014. Energy life-cycle assessment and $\mathrm{CO}_{2}$ emissions analysis of soybean-based biodiesel: a case study. J. Clean. Prod. 66, 233-241. https://doi.org/10.1016/j.jclepro.2013.10.041.

Raucci, G.S., Moreira, C.S., Alves, P.A., Mello, F.F.C., Frazão, L.A., Cerri, C.E.P., Cerri, C.C., 2015. Greenhouse gas assessment of Brazilian soybean production: a case study of Mato Grosso state. J. Clean. Prod. 96, 418-425. https://doi.org/10.1016/ j.jclepro.2014.02.064.

Rocha, M.H., Capaz, R.S., Lora, E.E.S., Nogueira, L.A.H., Leme, M.M.V., Réno, M.L.G. delOlmo, O.A., 2014. Life cycle assessment (LCA) for biofuels in Brazilian conditions: a meta-analysis. Renew. Sustain. Energy Rev. 37, 435-459. https:// doi.org/10.1016/j.rser.2014.05.036.

Salton, J.C., Mercante, F.M., Tomazi, M., Zanatta, J.A., Concenço, G., Silva, W.M. Retore, M., 2014. Integrated crop-livestock system in tropical Brazil: toward a sustainable production system. J. Clean. Prod. 190, 70-79. https://doi.org/ 10.1016/j.agee.2013.09.023.

Schuster, M.Z., Pelissari, A., de Moraes, A., Harrison, S.K., Sulc, R.M., Lustosa, S.B. Anghinoni, I., Carvalho, P.C., 2016. Grazing intensities affect weed seedling emergence and the seed bank in an integrated crop-livestock system. Agric. Econ. Environ. 232, 232-239. https://doi.org/10.1016/j.agee.2016.08.005.

Silva, A.S., Colozzi Filho, A., Nakatani, A.S., Alves, S.J., Andrade, D.S., Guimarães, M.F. 2015. Microbial characteristics of soils under an integrated crop-livestock system. Rev. Bras. Ciências Saúde 39 (1). https://doi.org/10.1590/ 01000683 rbcs20150185.

Tan, H.W., Aziz, A.R.A., Aroua, M.K., 2013. Glycerol production and its applications as a raw material: a review. Renew. Sustain. Energy Rev. 27, 118-127. https:// doi.org/10.1016/j.rser.2013.06.035.

UNFCCC, 1994. United Nations Framework Convention on Climate Change.

USDA, 2017. United States Department of Agriculture. World and U.S Supply and Use for Grains. April 2017. Available at: https://www.usda.gov/oce/commodity/ wasde/latest.txt (accessed: 27.04.17.). 